\title{
Influence of the concentrations of essential and toxic elements in the blood serum on the indicators of sperm quality in Arabian purebred stallions
}

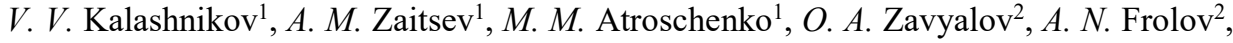 \\ and $M . Y a$. Kurilkina ${ }^{2}$ \\ ${ }^{1}$ All-Russian Research Institute of Horse Breeding, Russia \\ ${ }^{2}$ Federal Research Center for Biological Systems and Agricultural Technologies of the Russian \\ Academy of Sciences, Russia
}

\begin{abstract}
Analysis of trace elements in blood serum can be an important tool for monitoring micronutrient supply in stallions in order to maintain reproductive health. In this regard, the purpose of this study was to determine the relationship between the concentrations of macro- and microelements in the blood serum of stud stallions with the qualitative characteristics of fresh sperm and sperm after cryopreservation and thawing. The studies were carried out on purebred Arabian stallions $(n=50)$. As a biomaterial for studies, we used blood serum, fresh and thawed sperm after cryopreservation. The elemental composition of seminal plasma was determined by 25 chemical elements $\mathrm{Co}, \mathrm{Cr}, \mathrm{Cu}, \mathrm{Fe}, \mathrm{I}, \mathrm{Mn}, \mathrm{Se}, \mathrm{Zn} \mathrm{Ca}, \mathrm{K}$, $\mathrm{Mg}, \mathrm{P}, \mathrm{B}, \mathrm{Li}, \mathrm{Si}, \mathrm{V} \mathrm{Na}, \mathrm{Ni}, \mathrm{Sn}, \mathrm{Hg}, \mathrm{Sr}, \mathrm{Al}, \mathrm{As}, \mathrm{Cd}, \mathrm{Pb}$ ) by ICP-DRC-MS methods. It was found that the concentrations of $\mathrm{Mg}$ and $\mathrm{Co}$ in the blood serum positively correlate with the qualitative characteristics of the sperm of Arabian purebred stallions. Wherein, the optimal range of concentrations of $\mathrm{Mg}$ in the blood serum, typical for stallions with relatively high indicators of sperm quality, is 22.64 to $27.05 \mu \mathrm{g} / \mathrm{g}$; Co -0.001 to $0.0015 \mu \mathrm{g} / \mathrm{g}$.
\end{abstract}

\section{Introduction}

Currently, along with development of new reproductive technologies in animal husbandry, a search is underway for methods to recover the natural fertility of animals and humans. Moreover, chemical elements represent an important group of ecophysiological factors that determine the morphological and functional characteristics of the reproductive system $[1,2]$. Namely, it was found that the concentration of magnesium $(\mathrm{Mg})$ significantly correlates with the concentration of spermatozoa and the level of $\mathrm{Ca}$ in the seminal plasma of stallions [3]. Copper $(\mathrm{Cu})$ is an essential component of many metalloenzymes such as superoxide dismutase, ceruloplasmin and lysine oxidase, which are critical for antioxidant processes in sperm. It affects the progressive motility, viability, membrane integrity and prevents DNA damage after sperm dilution and cryopreservation $[4,5,6]$. Zinc ( $\mathrm{Zn})$ plays an important role in sperm motility and directly affects its morphology [7,8], and is also an important factor in the normal functioning of the prostate gland and the reproductive system as a whole [9, 
10, 11]. Ferrum $(\mathrm{Fe})$ deficiency reduces the activity of iron-containing and iron-dependent enzymes in seminal plasma [12]. Selenium (Se) has antioxidant properties and is essential for spermatogenesis and the maintenance of male fertility [13]. A high level of Lead (Pb) is associated with development of infertility caused by induction of a spontaneous premature acrosome reaction, and an increase in the concentration of $\mathrm{Pb}$ in seminal plasma may adversely affect the rates of in vitro fertilization $[14,15]$. Exposure to Cadmium $(\mathrm{Cd})$ can have a detrimental effect on reproductive function, causing atresia of ovarian follicles [16], uterine edema [17] and, in some cases, degeneration of the testes [18]. Previous studies have shown that administration of a certain dose of Cadmium decreases sperm motility [19]. Nickel (Ni) can impair the function of the testes, seminal vesicles and prostate [20]. In general, it can be stated that despite the large number of scientific papers published in recent years on the study of the effect of the metabolism of chemical elements in relation to reproductive functions, all of them mainly relate to humans, some agricultural species, and less often to stallions. Wherein, seminal plasma is more often used as a biosubstrate for assessing the exchange pool of chemical elements in the body. Wherein, the analysis of microelements in blood serum can be an important tool for monitoring the micronutrient supply of the body in order to maintain the reproductive health of farm animals $[21,22,23$, 24] and, namely, stallions [25].

In this regard, the purpose of this study was to determine the relationship between the concentrations of macro- and microelements in the blood serum of stud stallions with the qualitative characteristics of fresh sperm and sperm after cryopreservation and thawing.

\section{Materials and Methods}

\subsection{Study object}

The studies were carried out on stallions of the Arabian purebred horse breed. The live weight of stallions within sampling period was $410.5 \pm 25.3 \mathrm{~kg}$, age $-4-5$ years.

Animal care and experimental studies were performed in accordance with the instructions and recommendations of Russian Regulations, 1987 (Order No.755 on 12.08.1977 the USSR Ministry of Health) and "The Guide for Care and Use of Laboratory Animals (National Academy Press Washington, D.C. 1996)". Efforts have been made in the studies to minimize animal suffering and reduce the number of samples used.

\subsection{Experiment scheme}

Clinically healthy stallions of the Arabian purebred breed $(n=50)$ bred under the conditions of one biogeochemical province (Tersk pedigree stud farm No. 169, Stavropol Territory) were selected for the study. Blood serum, fresh sperm, and thawed sperm after cryopreservation were used as biosubstrates for the study.

At the first stage of the experiment, the correlation coefficients were calculated for concentrations of chemical elements in the blood serum and indicators of the quality of the sperm of stallions. At the second stage, based on the data on the levels of concentrations of chemical marker elements $(\mathrm{Co}, \mathrm{Mg})$ of reproductive qualities established within the first stage of the study, the stallions were divided into groups by the percentile method [26]: I up to the 25 th percentile, II — within the 25-75th percentile, III — above the 75 th percentile.

The conditions of feeding and keeping for all examined animals were identical. The consumed daily ration of feeding of experimental animals in the two-month period preceding sampling contained: $\mathrm{Ca}-77.3-97.5 \mathrm{~g}, \mathrm{P}-54.8-68.3 \mathrm{~g}, \mathrm{Fe}-740-930 \mathrm{mg}, \mathrm{Cu}-128-169 \mathrm{mg}$, $\mathrm{Zn}-440-550 \mathrm{mg}, \mathrm{Mn}-601-769 \mathrm{mg}, \mathrm{Co}-8.6-11.9 \mathrm{mg}, \mathrm{I}-8.1-12.3 \mathrm{mg}$. 


\subsection{Selection and analysis of sperm parameters}

Sperm intended for the study was obtained from stallions for a mare in season using an artificial vagina sample from the Horse Breeding VNII, with an interval of 48 hours. We received at least 5 ejaculates from each stallion. After a period of sexual rest in stallions, the sperm values of the first two ejaculates were not used in the treatment. After receiving sperm, each ejaculate was initially assessed according to the following indicators: volume, concentration, total sperm count in the ejaculate, progressive sperm motility, total sperm count with progressive motility in the ejaculate, sperm survival at a temperature (T) of 2-4 ${ }^{\circ} \mathrm{C}$. For dilution of sperm, we used lactose-chelate-citrate-yolk (LCCY) medium in a volume ratio of 1:3. Sperm were frozen in liquid nitrogen vapor using the technology of the Horse Breeding VNII. The frozen sperm was stored in liquid nitrogen at a temperature of $-196{ }^{\circ} \mathrm{C}$. The cryopreserved sperm was thawed in a water bath at a temperature of $40^{\circ} \mathrm{C}$ for 60 seconds. After thawing the cryopreserved sperm, the progressive motility and survival of spermatozoa were also determined at T $2-4{ }^{\circ} \mathrm{C}$. Sperm concentration (billion) was estimated using a digital photometer (IMV Technologies). Sperm activity (score) was studied using a phase contrast microscope (Nikon ECLIPSE E400, Tokyo, Japan).

\subsection{Selection and assessment of the elemental composition of blood serum}

Blood samples $(6 \mathrm{ml})$ were taken from the jugular vein in the upper third of the neck into vacuum tubes. Separation of serum was carried out by centrifuging the samples for 10 minutes at a speed of $1,000 \mathrm{~g}$. The content of elements was estimated using Elan 9000 mass spectrometer (Perkin Elmer, USA) and an Optima $2000 \mathrm{~V}$ atomic emission spectrometer (Perkin Elmer, USA). The elemental composition of seminal plasma was determined by 25 chemical elements (Co, Cr, Cu, Fe, I, Mn, Se, Zn Ca, K, Mg, P, B, Li, Si, V Na, Ni, Sn, Hg, $\mathrm{Sr}, \mathrm{Al}, \mathrm{As}, \mathrm{Cd}, \mathrm{Pb})$.

\subsection{Statistical analysis}

Correlation coefficients were calculated according to Spearman $\left(\mathrm{K}_{\mathrm{s}}\right)$. To test the hypothesis about the normal distribution of other quantitative traits, the Shapiro-Wilk test was used. Significance of differences was checked using the Mann-Whitney U test. Significance level (P) was taken to be less than or equal to 0.05 . The data were processed using Statistica 10.0 software package (Stat Soft Inc., USA).

\section{Result}

Correlation analysis showed that the survival rate of spermatozoa in fresh sperm at T $2-4{ }^{\circ} \mathrm{C}$ is reliably associated with the level of $\mathrm{Mg}$ in the blood serum, the concentration of spermatozoa is positively correlated with the level of Co (Table 1). 
Table 1. Correlation coefficients for the concentrations of chemical elements in the blood serum and indicators of sperm quality in Arabian purebred stallions, $\mathrm{K}_{\mathrm{s}}$

\begin{tabular}{|c|c|c|c|c|c|c|}
\hline \multirow[b]{2}{*}{$\underset{t}{\text { Elemen }}$} & \multicolumn{6}{|c|}{ Sperm quality indicators } \\
\hline & $\begin{array}{l}\text { Ejaculat } \\
\text { e } \\
\text { volume } \\
\text { after } \\
\text { filtration } \\
\quad, \mathrm{ml}\end{array}$ & $\begin{array}{c}\text { Sperm } \\
\text { concentratio } \\
\mathrm{n}, \mathrm{mln} / \mathrm{ml}\end{array}$ & $\begin{array}{l}\text { Progressiv } \\
\text { e sperm } \\
\text { motility in } \\
\text { fresh } \\
\text { sperm, \% }\end{array}$ & $\begin{array}{c}\text { Sperm } \\
\text { surviva } \\
1 \text { in } \\
\text { fresh } \\
\text { sperm } \\
\text { at T } 2- \\
4{ }^{\circ} \mathrm{C}, \\
\text { hour }\end{array}$ & $\begin{array}{c}\text { Progressive } \\
\text { sperm motility } \\
\text { after } \\
\text { cryopreservation, } \\
\%\end{array}$ & $\begin{array}{c}\text { Sperm survival } \\
\text { after } \\
\text { cryopreservatio } \\
\text { n at T } 2-4^{0} \mathrm{C}, \\
\text { hour }\end{array}$ \\
\hline \multicolumn{7}{|c|}{ Macroelements } \\
\hline $\mathrm{Ca}$ & -0.09 & 0.14 & -0.13 & 0.25 & 0.16 & 0.22 \\
\hline $\mathrm{K}$ & 0.20 & 0.02 & -0.07 & 0.00 & -0.27 & -0.15 \\
\hline $\mathrm{Mg}$ & -0.13 & -0.02 & -0.02 & $0.46^{*}$ & 0.27 & 0.28 \\
\hline $\mathrm{P}$ & 0.21 & -0.13 & -0.03 & -0.14 & -0.33 & -0.27 \\
\hline \multicolumn{7}{|c|}{ Essential microelements } \\
\hline Co & -0.09 & $0.41 *$ & -0.25 & 0.11 & 0.10 & 0.09 \\
\hline $\mathrm{Cr}$ & 0.24 & -0.01 & 0.02 & -0.12 & -0.33 & -0.26 \\
\hline $\mathrm{Cu}$ & 0.13 & 0.19 & -0.10 & 0.04 & -0.31 & -0.08 \\
\hline $\mathrm{Fe}$ & -0.17 & 0.05 & 0.06 & 0.23 & 0.07 & 0.06 \\
\hline I & 0.21 & -0.16 & 0.25 & 0.17 & 0.19 & 0.04 \\
\hline $\mathrm{Mn}$ & 0.06 & 0.06 & -0.19 & -0.07 & -0.17 & -0.13 \\
\hline $\mathrm{Se}$ & 0.19 & 0.10 & -0.12 & -0.26 & -0.06 & -0.02 \\
\hline $\mathrm{Zn}$ & -0.04 & -0.03 & -0.21 & 0.00 & 0.00 & -0.06 \\
\hline \multicolumn{7}{|c|}{ Conditionally essential microelements } \\
\hline $\mathrm{Li}$ & -0.14 & 0.35 & 0.19 & -0.03 & 0.21 & 0.21 \\
\hline $\mathrm{Ni}$ & -0.06 & 0.24 & -0.08 & -0.06 & -0.39 & -0.19 \\
\hline $\mathrm{V}$ & 0.21 & -0.08 & 0.14 & 0.05 & -0.21 & -0.15 \\
\hline B & -0.10 & 0.28 & 0.29 & -0.01 & 0.10 & 0.19 \\
\hline \multicolumn{7}{|c|}{ Toxic elements } \\
\hline $\mathrm{Cd}$ & 0.14 & -0.17 & 0.24 & -0.10 & -0.15 & -0.14 \\
\hline $\mathrm{Hg}$ & 0.20 & -0.16 & 0.14 & -0.26 & -0.31 & -0.25 \\
\hline $\mathrm{Pb}$ & -0.02 & 0.08 & 0.11 & -0.24 & -0.18 & -0.19 \\
\hline $\mathrm{Sn}$ & -0.28 & 0.14 & -0.01 & -0.18 & -0.25 & -0.07 \\
\hline $\mathrm{Sr}$ & 0.26 & -0.19 & 0.05 & -0.12 & -0.21 & -0.18 \\
\hline $\mathrm{Al}$ & -0.08 & 0.14 & -0.27 & -0.19 & -0.18 & -0.14 \\
\hline As & 0.03 & -0.08 & 0.15 & -0.10 & -0.25 & -0.20 \\
\hline
\end{tabular}

Due to the fact that a significant correlation was established only for $\mathrm{Mg}$ and $\mathrm{Co}$, these elements were selected for further analysis.

Cobalt 
Comparative analysis of data on the concentration of Co in the blood serum of stallions in the context of formed groups showed that the blood serum of stallions of group III contained $0.0012 \pm 0.000213 \mu \mathrm{g} / \mathrm{g}$, which is $39.7(\mathrm{P} \leq 0.001)$ and $103.7 \%(\mathrm{P} \leq 0.001)$ is higher in comparison with groups I and II (Fig. 1). In this case, the actual range of variation of Co concentration in the blood serum of stallions of group I was from 0.00032 to $0.00067 \mu \mathrm{g} / \mathrm{g}$, II — from 0.00068 to $0.00099 \mu \mathrm{g} / \mathrm{g}$, group III — from 0.001 to $0.0015 \mu \mathrm{g} / \mathrm{g}$.

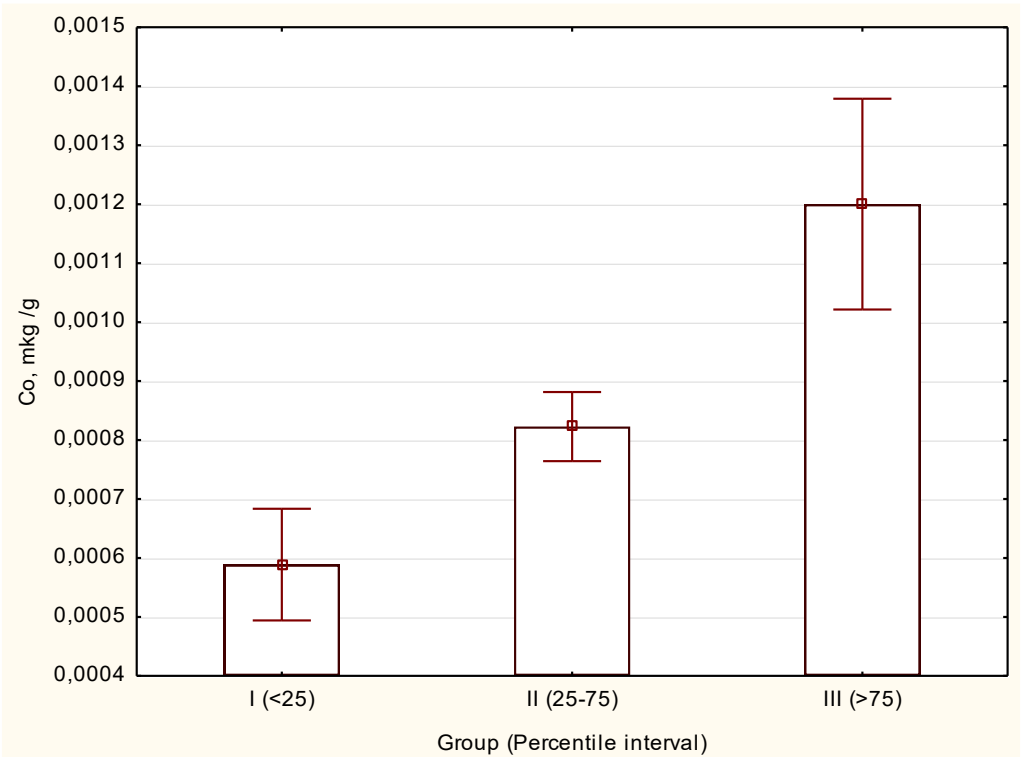

Fig. 1. Co concentration in the blood serum of stallions depending on the selected percentile interval, $\mu \mathrm{g} / \mathrm{g}$

The results obtained in our study demonstrated a positive trend in the indicators of sperm quality as the concentration of Co in the blood serum increased (Table 2).

Table 2. Indicators of sperm quality of Arabian purebred horse stallions depending on the concentration of $\mathrm{Co}$ in the blood serum

\begin{tabular}{|l|c|c|c|}
\hline \multirow{2}{*}{ Indicators } & \multicolumn{3}{|c|}{ Group (percentile interval) } \\
\cline { 2 - 4 } & $(<25)$ & II (25-75) & III (>75) \\
\hline $\begin{array}{l}\text { Ejaculate volume after } \\
\text { filtration, ml }\end{array}$ & $29.63 \pm 7.78$ & $27.21 \pm 11.83$ & $33.63 \pm 11.26$ \\
\hline $\begin{array}{l}\text { Sperm concentration, } \\
\text { mln/ml }\end{array}$ & $299.1 \pm 77.75$ & $211.9 \pm 96.38$ & $228.1 \pm 110.1$ \\
\hline $\begin{array}{l}\text { Progressive sperm motility } \\
\text { in fresh sperm, \% }\end{array}$ & $53.38 \pm 8.19$ & $59.71 \pm 12.34$ & $63.13 \pm 9.23 *$ \\
\hline $\begin{array}{l}\text { Sperm survival in fresh } \\
\text { sperm at T 2-4 }{ }^{0} \text { C, hour }\end{array}$ & $123.0 \pm 44.32$ & $136.3 \pm 49.95$ & $147.0 \pm 123.0$ \\
\hline $\begin{array}{l}\text { Progressive sperm motility } \\
\text { after cryopreservation, \% }\end{array}$ & $20.06 \pm 10.22$ & $29.24 \pm 14.02$ & $21.42 \pm 13.58$ \\
\hline $\begin{array}{l}\text { Sperm survival after } \\
\text { cryopreservation at T 2-4 } \\
{ }^{0} \text { C, hour }\end{array}$ & $53.00 \pm 42.80$ & $74.57 \pm 37.11$ & $60.75 \pm 65.60$ \\
\hline
\end{tabular}

$* P \leq 0.05$ compared to group $I$

The lowest rate of progressive sperm motility in fresh sperm was observed in animals with serum Co content below the 25 th percentile. As the Co content increased from minimum 
to maximum in percentile intervals of $25-75$ and more than 75 percentile, this indicator increased by 11.9 and $18.3 \%(\mathrm{P} \leq 0.05)$.

\section{Magnesium}

The actual differences between groups of stallions in terms of serum $\mathrm{Mg}$ concentration are shown in Figure 2.

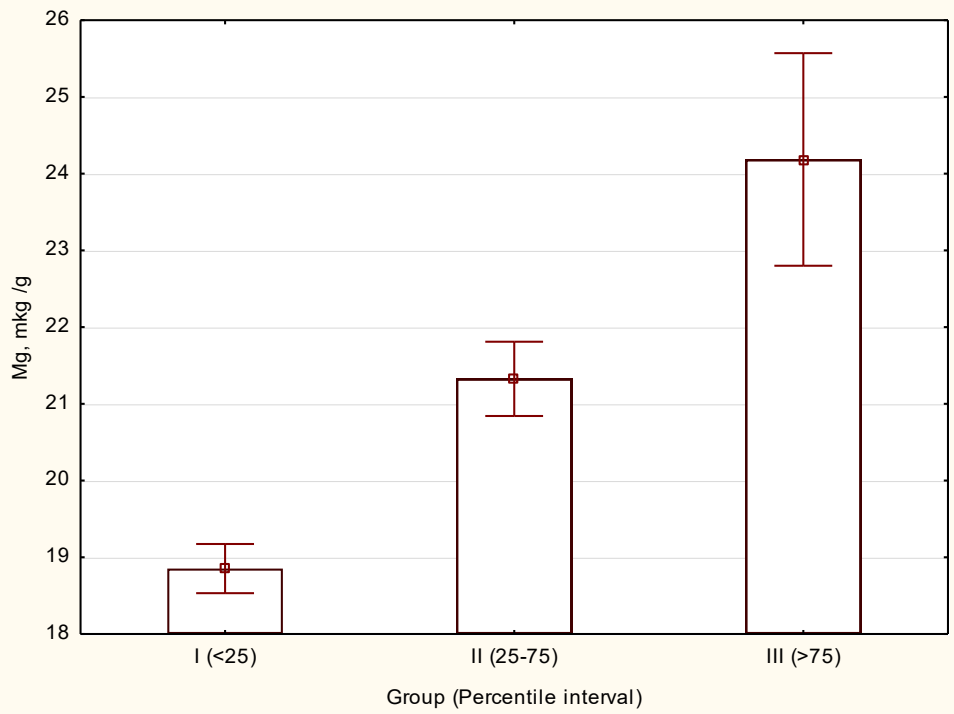

Fig. 2. Concentration of $\mathrm{Mg}$ in the blood serum of stallions depending on the selected percentile interval, $\mu \mathrm{g} / \mathrm{g}$

The blood serum of animals of group I contained $18.85 \pm 0.384 \mu \mathrm{g} / \mathrm{g} \mathrm{Mg}$, which is 11.63 $(\mathrm{P} \leq 0.001)$ and $22.08 \%(\mathrm{P} \leq 0.001)$ less in comparison with groups II and III. Wherein, the range of $\mathrm{Mg}$ concentrations in the blood serum of group I stallions was from 18.16 to 19.43 $\mu \mathrm{g} / \mathrm{g}$, from 19.79 to $22.37 \mu \mathrm{g} / \mathrm{g}$ in group II stallions, from 22.64 to $27.05 \mu \mathrm{g} / \mathrm{g}$ in group III stallions.

The qualitative indicators of sperm in the compared groups, in our study, increased as the concentration of $\mathrm{Mg}$ in the blood serum increased (Table 3).

Table 3. Indicators of sperm quality of Arabian purebred horse stallions depending on the concentration of $\mathrm{Mg}$ in the blood serum

\begin{tabular}{|c|c|c|c|}
\hline \multirow{2}{*}{ Indicators } & \multicolumn{3}{|c|}{ Group (percentile interval) } \\
\hline & $\mathrm{I}(<25)$ & II (25-75) & III $(>75)$ \\
\hline $\begin{array}{l}\text { Ejaculate volume after filtration, } \\
\mathrm{ml}\end{array}$ & $30.50 \pm 11.03$ & $29.00 \pm 12.69$ & $29.71 \pm 6.05$ \\
\hline Sperm concentration, $\mathrm{mln} / \mathrm{ml}$ & $232.4 \pm 91.34$ & $256.7 \pm 108.11$ & $210.7 \pm 96.07$ \\
\hline $\begin{array}{l}\text { Progressive sperm motility in } \\
\text { fresh sperm, } \%\end{array}$ & $58.38 \pm 11.58$ & $57.67 \pm 8.37$ & $62.29 \pm 15.38$ \\
\hline $\begin{array}{l}\text { Sperm survival in fresh sperm at } \\
\text { T } 2-4^{0} \mathrm{C} \text {, hour }\end{array}$ & $90.00 \pm 32.71$ & $132.0 \pm 41.32 *$ & $195.4 \pm 116.3^{*}$ \\
\hline $\begin{array}{l}\text { Progressive sperm motility after } \\
\text { cryopreservation, } \%\end{array}$ & $18.67 \pm 16.86$ & $25.19 \pm 12.56$ & $30.57 \pm 8.06$ \\
\hline $\begin{array}{l}\text { Sperm survival after } \\
\text { cryopreservation at } \mathrm{T} 2-4{ }^{0} \mathrm{C} \text {, } \\
\text { hour }\end{array}$ & $40.25 \pm 41.16$ & $64.80 \pm 45.99$ & $94.29 \pm 42.95 *$ \\
\hline
\end{tabular}

$* P \leq 0.05$ compared to group I 
Stallions with a serum $\mathrm{Mg}$ concentration of less than the 25th percentile (group I) were characterized by minimal values of sperm survival rates in fresh and thawed sperm after cryopreservation. As the $\mathrm{Mg}$ content increased from minimum to medium (group II) and maximum (group III), there was an increase in sperm survival in fresh sperm by $46.7(\mathrm{P} \leq 0.05)$ and $117.0 \%(\mathrm{P} \leq 0.05)$; in sperm thawed after cryopreservation by 60.8 and $134.0(\mathrm{P} \leq 0.05)$, respectively.

\section{Discussion}

Comparison of sperm parameters obtained from stallions with different levels of chemical elements in the blood serum revealed a number of significant differences. An explanation of this fact is possible considering information on the concentration of elements in the blood serum as a characteristic reflecting the exposure of elements from the diet [27] and, in general, associated with the size of the exchange pool of these substances in the animal's body [28]. On the other hand, a close relationship is known between the elemental status of stallions and their reproductive qualities $[29,30]$, which in turn is determined by the influence of elements on spermatogenesis and sperm quality in mammals [31, 32, 33]. For this reason, the significant influence of the concentrations of microelements in the blood serum on the qualitative characteristics of the sperm of stallions revealed by us is quite understandable. However, despite the fact that in our experiment an increase in progressive sperm motility in fresh sperm was found by $11.9-18.3 \%$ as the content of Co in the blood serum increased, in the vast majority of previous studies, negative effects of Co on male fertility were demonstrated. Namely, it was found that Co ions in extremely low concentrations exhibit powerful immobilizing properties of spermatozoa, leading to the destruction of thiol groups on the surface of spermatozoa, which provokes an increased formation of superoxide anion radicals and makes them the most likely sources of oxidative stress [34, 35]. Spermatozoa are sensitive to oxidative stress due to the lack of cytoplasmic protection [36, 37, 38]. In some cases, an excess of Co can manifest itself in the form of a decrease in motility and an increase in the number of abnormal spermatozoa [39, 40, 41] and disruption of the mechanisms of testosterone synthesis [42].

Another important element of cell physiology is $\mathrm{Mg}$, which is present in high concentration in the sperm of stallions [43]. Previous studies have shown that the concentration of $\mathrm{Mg}$ in sperm is closely related to progressive motility, general motility and sperm viability [44, 45, 46]. In addition, $\mathrm{Mg}$ is considered a marker of seminal vesicle secretion and acts as an intracellular calcium antagonist [47]. In our experiment, results demonstrating a positive relationship between the level of $\mathrm{Mg}$ in the blood serum and the survival of sperm in fresh and thawed sperm after cryopreservation were obtained (Tables 1 , 3). It shall be noted that a similar nature of the interaction of $\mathrm{Mg}$ with the quality characteristics of sperm has been reported in other publications. Namely, a relationship was found between the concentration of $\mathrm{Mg}$ in the blood serum and the survival of spermatozoa within hypothermic storage of diluted sperm $(r=0.46)$ in Arabian purebred stallions [25]. It was also reported that $\mathrm{Mg}$ levels were positively correlated with sperm viability in rams [48]. As one of the probable reasons for this nature of the interaction, it is possible to consider the physiological role of $\mathrm{Mg}$ within implementation of the function of maintaining the osmotic balance necessary for the function and fertility of spermatozoa, as well as its interaction with enzymes such as $\mathrm{Ca}^{2+}$-dependent $\mathrm{Mg}^{2+}$ - ATPase [49]. In addition, it is believed that $\mathrm{Mg}$ can reduce the intensity of lipid peroxidation in the seminal fluid of males by inhibiting the metabolism of $\mathrm{Cd}$ [50]. For this reason, $\mathrm{Mg}$ supplements are often viewed as antidotes to the toxic effects of $\mathrm{Cd}$ on the reproductive system in laboratory animals [50]. Wherein, in some studies, no positive effect of $\mathrm{Mg}$ on the indicators of the quality of sperm of stallions was found $[51,52]$, which determines the prospects for further study. 


\section{Conclusions}

Therefore, it was found that the concentrations of $\mathrm{Mg}$ and Co in the blood serum are positively correlated with the qualitative characteristics of the sperm of Arabian purebred stallions. Wherein, the optimal range of concentrations of $\mathrm{Mg}$ in the blood serum, typical for stallions with relatively high indicators of sperm quality, is 22.64 to $27.05 \mu \mathrm{g} / \mathrm{g}$; Co -0.001 to $0.0015 \mu \mathrm{g} / \mathrm{g}$.

\section{Acknowledgments}

The research was carried out with the support of the Russian Science Foundation (project No. 17-16-01109 P).

\section{References}

1. V.A. Bagirov, V.V. Kalaschnikov, A.M. Zaitsev, O.A. Zavialov, A.N. Frolov, Sel'skokhozyaistvennaya Biologiya, 52(6), 1184-1193 (2017)

2. H. Bertelsmann, S. Keppler, M. Höltershinken, H. Bollwein, D. Behne, D. Alber, G. Bukalis, A. Kyriakopoulos, H. Sieme // Reprod Fertil Dev. 2010;22(5). P. 886-91.

3. Lu Sy., Huang ZM., Huang WK., Liu XY., Chen YY., Shi T., et al. Proteins, 81(5), 74053 (2013)

4. Vyvial, Michal, et al. Acta Veterinaria Brno, 88.4, 377-384 (2020)

5. ElSaid, Halla, et al. Benha Veterinary Medical Journal, 37.1, 210-215 (2019)

6. Tabassomi, Mehdi, and Sayed Mortaza Alavi-Shoushtari, Veterinary research forum: an international quarterly journal, 4(1) (2013)

7. Z. Liu, L. Chen, Y. Shang, P. Huang, L. Miao, Development, 140(10), 2103-2107 (2013)

8. AIS. Villaverde, EG. Fioratti, RS. Ramos, RC. Neves, JCP. Ferreira, GS. Cardoso, et al. Blood and seminal plasma concentrations of selenium, zinc and testosterone and their relationship to sperm quality and testicular biometry in domestic cats. Anim Reprod Sci. 2014; 150(1):50-5.

9. W.Y. Wong, G. Flik, P.M. Groenen, D.W. Swinkels, C.M. Thomas, J.H. CopiusPeereboom, H.M. Merkus, R.P. Steegers-Theunissen, Reprod Toxicol, 15(2), 131-136 (2001)

10. B. Eskenazi, S.A. Kidd, A.R. Marks, E. Sloter, G. Block, A.J. Wyrobek, Hum Reprod, 20, 10 (2005)

11. V. Cigankova, P. Mesaros, J. Bires, V. Ledecky, J. Ciganek, E. Tomajkova, Slov Vet J, 23, 97-100 (1998)

12. P. Mudron, W. Baumgartner, G. Kovac, P. Bartko, I. Rosival, I. Zezula, Dtsch Tieraztl Wschr, 103, 131-133 (1996)

13. Mahdiyeh Mirnamniha, Fereshteh Faroughi, Eisa Tahmasbpour, Pirooz Ebrahimi and Asghar Beigi Harchegani, From the journal Reviews on Environmental Health (2019)

14. S. Benoff, G.M. Centola, C. Millan, B. Napolitano, J. L. Marmar, I. R. Hurley Hum, Reprod, 18, 374-383 (2003)

15. J.P. Bonde, M. Joffe, P. Apostoli, A. Dale, P. Kiss, M. Spano, et al. Occup Environ Med, 59, 234-242 (2002)

16. P. Massanyi, V. Uhrin, Reprod Dom Anim, 31, 629-632 (1996)

17. P. Massanyi, V. Uhrin, J Environ Sci Health, 32, 1459-1466 (1997) 
18. R. Toman, P. Massanyi, Trace Elem Electrolytes, 19, 114-117 (2002)

19. P. Massanyi, K. Massanyiova, F. Pizzi, J. Trandzik, R. Toman, Agriculture, 45, 287-295 (1999)

20. Zs Forgacs, Zs Nemethy, Cs Revesz, P. Lazar, J Toxicol Environ Health, A62, 349$358(2001)$

21. J.F. Vázquezarmijo, R. Rojo, D. López, J.L. Tinoco, A. González, N. Pescador, et al., Tropical and Subtropical Agroecosystems, 14, 1-13 (2016)

22. E. Humann-Ziehank, M. Ganter, I. Hennig-Pauka, A. Binder, Small Rumin Res, 75, 185 $191(2008)$

23. Y.H. Wu, W. Lai, Z.H. Liu, H.K. Wei, Y.F. Zhou, J.J. Tan, et al., Biol Trace Elem Res, 10 (2018)

24. M. Zakošek Pipan, P. Zrimšek, B. et al. Macro- and microelements in serum and seminal plasma as biomarkers for bull sperm cryotolerance. Acta Vet Scand 63, 25 (2021)

25. V.V. Kalashnikov, M.M. Atroshchenko, A.M. Zaitsev, A.A. Nezalenova, A.A. Datsyshin, XIX International Scientific and Practical Conference "Current Trends of Agricultural Industry in Global Economy", 112-117 (2020)

26. M. G. Skalnaya, V. A. Demidov, A. V. Skalny, Micro-elements in medicine, 4(2), 510 (2003)

27. K. Chojnacka, A. Zielińska, I. Michalak, H.Górecki, Environ Toxicol Pharmacol, 30(2), 188-194 (2010)

28. S.V. Lebedev, G.K. Duskaev, O.V. Kvan, E.V. Sheida, I. Alijanova, S.G. Rakhmatullin, S.A. Miroshnikov, Biol Med (Aligarh), 7(4), 1-6 (2015)

29. S.M. Ghallab, A.M. Shahat, A.M. Fadl, M.M. Ayoub, A.R. Moawad, Cryobiology, S0011-2240(17), 30213-30214 (2010)

30. A. Contri, I. De Amicis, A. Molinari, M. Faustini, A. Gramenzi, D. Robbe, A. Carluccio, Theriogenology, 75(7), 1319-1326 (2019)

31. S. Hamameh, J-L. Gatti, Hum Reprod, 13(4), 20-30 (1998)

32. S.E. Chia, C.N. Ong, L.H. Chua, L.M. Ho, S.K, Tay. J Androl., 21, 53-57 (2000)

33. P. Massanyi, J. Trandzik, P. Nad, R. Toman, M. Skalick, B. Kornekov, Asian J Androl, 5, 101-104 (2003)

34. G. Pradeep Kumar, Malini Laloraya, Manmohan M. Laloraya, Contraception, 41(6), 633639

35. S.J. Stohs, D. Bagchi, Free Radic Biol Med, 18, 321 (1995)

36. E.T. Donnelly, N. McClure, S.E. Lewis, Fertil Steril, 72, 484 (1999)

37. R.A. Saleh, A. Agarwal, J Androl, 23, 737 (2002)

38. E Kawakami, A Tekemura, M Sakuma, M Takano, T Hirano, T Hori, T Tsutsui, J Vet Med Sci, 69(2), 133-136 (2007)

39. J.R. Bucher, M.R. Elwell, M.B. Thompson, et al. Fundam Appl Toxicol, 15, 357 (1990)

40. U. Marzec-Wróblewska, P. Kamiński, P. Łakota, et al. Biol Trace Elem Res, 188, 251260 (2019)

41. Kocabaş, Mehmet, Filiz Kutluyer, Bulletin of environmental contamination and toxicology, 99.6, 690-694 (2017)

42. N.G. Pedigo, W.J. George, M.B. Anderson, Reproductive Toxicology, 2(1), 45-53 (1988)

43. Halo Jr, Marko, et al., The Journal of Microbiology, Biotechnology and Food Sciences, 7.5, $516(2018)$ 
44. M. Eghbali, S.M. Alavi Shoushtari, S. Asri Rezaei, M.H. Khadem Ansari, Veterinary research forum, 1(1), 12-20

45. A. Kasperczyk, et al., Magnesium Research, 28(1), 14-22 (2015)

46. Zhonghua nan ke xue, National Journal of Andrology, 16(11), 1019-1022 (2010)

47. M. Eghbali, S.M. Alavi Shoushtari, S. Asri Rezaei, M.H. Khadem Ansari, Veterinary research forum, 1(1), 12-20 (2020)

48. H Abdel-Rahman, MS El-Belely, AA Al-Qarawi, et al., Small Rumin Res, 38(1), 4549 (2000)

49. NS Juyena, C. Stelletta, J Androl, 33(4), 536-551 (2012)

50. N. Babaknejad, S. Bahrami, A.A. Moshtaghie, Biol Trace Elem Res, 185, 106-115 (2018)

51. M. Mrackova, M. Zavadilova, M. Sedlinska, Mac Vet Rev, 38(1), 91-96 (2015)

52. A. Usuga, B. Rojano, G. Restrepo, J Equine Vet Sci, 58, 103-111 (2017) 